\title{
ENVIRONMENTAL IMPACTS OF RENEWABLE ENERGY IN EGYPT (REVIEW ARTICLE)
}

\author{
By \\ El Safty AMK and Siha MS \\ Department of Occupational and Environmental Medicine, Faculty of \\ Medicine, Cairo University. \\ Corresponding author: El Safty AMK.Email: amalelsafty@kasralainy.edu.eg
}

\begin{abstract}
Egyptian rapidly growing population and establishing energy-intensive industrial facilities demanded large supply of power to maintain that growth. Egypt is a country well suited for alternative energy production. It has strong, steady wind, good solar energy and the hydrothermal resources from the Nile. The government decided to improve the diversity of energy by embracing opportunities from renewable sources as solar and wind in the energy mix, to bring the balance back to Egypt's energy market. Environmental impact assessment (EIA), should be considered in all stages starting from planning, site selection, type of technology used, and installing phase. Life cycle assessment tool is used as a method to know the average environmental impact of different renewable energy source for appropriate planning and proper decision making. This showed the importance of generating awareness towards environmental impact of various renewable energy systems.
\end{abstract}

Key words: Environmental impact assessment, Renewable energy, Wind energy, Solar energy and Life cycle assessment. 


\section{Introduction}

\section{Background:}

Renewable energy is going to be an important source for power generation in the future, because we can use these resources several times to produce valuable energy. The energy resources are normally classified into fossil resources, renewable, and nuclear energy resources. Different renewable energy resources, like hydropower, wind, solar, biomass, ocean energy, biofuel, geothermal, etc., provide $15-20 \%$ of the total world's energy. The world is going to change into a global small village due to extra need of energy due to rapid growing of the population, which leads to the use of fossil fuels like coal, gas, and oil to fulfill the energy requirement. The latter will create many problems like depletion of fossil fuels, environmental and geographical conflicts, greenhouse effect, global warming, and fluctuation in fuel prices (Kumar, 2020).

Renewable energy resources have the capability to satisfy the world's energy demand, to protect the environment, to offer energy security and economic benefits. Renewable energy resources are nearby over wide geographical areas, in contrast to other energy sources, which are present in a limited number of countries (https://en.wikipedia.org/ wiki/Renewable_energy).

It would also diminish environmental pollution such as air pollution caused by burning of fossil fuels which have a negative impact on human health, such as respiratory and cardiovascular diseases, reduce premature mortalities and decrease related health costs (PabloRomero et al., 2016). Renewable technologies are also appropriate to rural and developing countries, where energy is often essential in human development (Jacobson et al, 2015).

Despite the fact that Egypt is the largest non-OPEC oil (Organization of the Petroleum Exporting Countries) producer in Africa and the second largest gas producer in the continent, besides its significant role in regional and global energy markets, recently, the country's energy status faced a variety of conflicting and overlapping challenges that caused shortage of energy production (Bahgat., 2013). This mandates thinking of other sources than oil, natural gas, and hydrothermal. The idea of increasing the contribution of renewable energy to electricity production to face the challenges of increasing demands is adopted by the Egyptian 
government, as Egypt has strong energy production capabilities. (https:// www.energycharter.org/fileadmin/ DocumentsMedia/Occasional/ Egypt_and_the_Charter.pdf). Renewable energy sources can renew themselves within a short time or are permanently available as wind and solar sources. The laws and legislations that have been adopted recently by the Egyptian government encouraged the private sector to invest in the renewable energy sector and allowed the sale of electricity by individuals and companies to the national network. More efforts are needed to revise environmental impact assessment of renewable energy sources (https://wwww.dailynews segypt. com/2020/01/15/a-positive-outlookfor-renewable-energy-investments-inegypt/).

\section{1- The need for renewable energy:}

Most countries are still subsidizing the consumption of fossil fuels (cigionline.org/articles/ipcc-reportwill-have-profound-effects-climate-go vernance?gclid=EAIaIQobChMIluzV1 OiK6AIVWofVCh2PTgY0EAAYASA AEgKVhfD_BwE).

Fossil-fuel combustion is the main cause for the emission of carbon dioxide $\left(\mathrm{CO}_{2}\right)$, greenhouse gases (GHG), nitrogen oxide $\left(\mathrm{NO}_{\mathrm{x}}\right)$ and sulfur dioxide $\left(\mathrm{SO}_{2}\right)$. Oxides of nitrogen $\left(\mathrm{NO}_{\mathrm{x}}\right)$ are responsible for forming ground-level ozone, nitric acid, and particle-phase ammonium nitrate. Sulfur oxides react in the atmosphere to form sulfuric acid and ammonium sulfate, both lead to human illnesses, visibility reduction, eutrophication and acid deposition. The production of electricity also have high demands of water and land (http:// www.conserve-energy-future.com/ disadvantages_fossilfuels.php,)

Pablo-Romero et al. 2016 stated that greenhouse gases will elevate the average temperature in the next 50 years by between $2^{\circ} \mathrm{C}$ and $3^{\circ} \mathrm{C}$, which represent a hazard to the essential elements of human life in different parts of world: access to water, food production, health, land use, and environment. Also, the Intergovernmental Panel on Climate Change (IPCC) which is an intergovernmental body of the United Nations that is devoted to provide the world with objective, scientific information related to understanding the scientific basis of the danger of humaninduced climate change, its natural, political, and economic impacts. Its latest report 2018 declared a rise of global warming by $1.5^{\circ} \mathrm{C}$ of above the 
preindustrial levels. It also detected that approximately a decade remains to keep global warming below this level and avoid the most horrible effects of climate change (cigionline.org/articles/ ipcc-report-will-have-profound-effectsclimate-governance?gclid=EAIaIQobC hMIluzV1OiK6AIVWofVCh2PTgY0E AAYASAAEgKVhfD_BwE).-

To put an end for the harmful effects and unfortunate mishaps caused by fossil fuel, urgent action should be implemented to change energy systems for increasing use of renewable energy to meet the objectives of United Nations Sustainable Development goal. Renewable energy are derived from infinite hygienic sources and are considered now as clean, inexhaustible and competitive to fossil fuel because of their diversity, abundance all over the planet. Above all they produce neither greenhouse gases nor polluting emissions (Shahzad , 2015).

During the last decade, the worldwide expansion of renewable energy has progressed rapidly. According to the International Energy Agency (IEA) world electricity demand will have increased by $70 \%$ by 2040 . According to the International Renewable Energy Agency (IRENA), doubling the renewable energy share in the world energy mix, to $36 \%$ by 2030 , will result in additional global growth off $1.1 \%$ by that year, an increase in wellbeing of $3.7 \%$ and in employment in the sector of up to more than 24 million people, compared to 9.2 million today. In many parts of the world, renewable energy sources represent the lowest-cost of new power generation technology, and costs continue to decline. Also it increased reliability and resilience of the energy system and energy supply.

\section{2- History of renewable energy in Egypt:}

Electricity was first introduced in Egypt in 1893. The Egyptian sources of energy mixture are not properly diversified. The three major sources of Egyptian energy production are from oil and natural gas (that represent about $90 \%$ of population use), and the hydroelectric power which constitutes approximately $11.2 \%$ of Egypt's power. The first of which (Aswan Dam) was built in 1960 to control the Nile water release for irrigation. It saves from 5 to $10 \%$ of Egypt's annual energy requirements. In 1967, the High Dam hydropower plant was built, followed by the construction of the Aswan-2 power plant in 1985 , the Isna hydro 
power plant in 1993 and that of NagaHamadi in 2008 (EIA, 2018)).

Hydropower technology depends on gravity and the height the water falls down on to the turbine (Park, 2015).

In 1986, the Egyptian government established of the New and Renewable Energy Authority (NREA) to enhance renewable energy placement. The NREA focuses mainly on wind and solar technologies, and other institutions are devoted to enhance biomass development.

\section{3- Renewable energy in Egypt:}

The recognition of the need to maintain diverse energy sources remains important, given that Egypt is becoming increasingly dependent on a local single source - gas - which also has an export market value. Egypt has experienced an energy supply deficit due to the rapid increase in energy consumption and the depletion of domestic oil and gas resources. Because of fiscal imbalances and energy shortages, the government introduced a comprehensive program that included renewable energy to face the challenges to secure adequate power production.

4(a): Solar energy: Egypt has a high solar availability because of hot desert climate. The majority of solar energy available in the country was derived from small-scale projects. Solar energy technology is obtained from solar irradiance to generate electricity using photovoltaic (PV) and concentrating solar power (CSP), to produce thermal energy, to meet direct lighting needs and, potentially, to produce fuels that might be used for transport and other purposes (Edenhofer et al., 2011).

Egypt began laying the groundwork for Benban project in the eastern region of the Sahara Desert (the first utilityscale solar PV project), after enduring repeated blackouts, caused by severe fuel shortages that reached their worst point in August 2014. Benban is the second best spot for solar power plants, behind the Chilean desert highlands. At the time, peak demand was $28 \mathrm{GW}$ but the country's production was limited to just $24 \mathrm{GW}$ (https://spectrum.ieee.org/ energywise/energy/renewables/egyptsmassive-18gw-benban-solar-parknears-completion).

4(b): Wind energy: According to the National Wind Atlas, it is known that Egypt enjoys strong wind at an average speed on 10.5 miles per second. Egypt has accordingly started building the biggest wind farm, in terms of area, num- 
ber of turbines and capacities generated Electricity \& Energy has formulated its from the plant, in the Zafarana district national strategy in the field of New and (2010) and Gabal el-Zeit area (2014) of Renewable Sources of Energy (NRSE) the Red Sea governorate (https://www. egypttoday.com/Article/2/62730/2018The-year-of-new-renewable-energy).

Egypt $>$ s resolution to increase the use of renewable energy sources is driven in part by environmental considerations, and in part by an interest in diversification of energy supply. In Early 1980`s , the Egyptian Ministry of as an integral part of its global energy strategy. The strategy targeted to supply $20 \%$ of the country's total primary needs, from NRSE by the year 2022 and 42 percent by 2035. The Priority has been given to wind and solar energy sources (https://www.oecd.org/greengrowth/greening-energy/49157219. pdf).

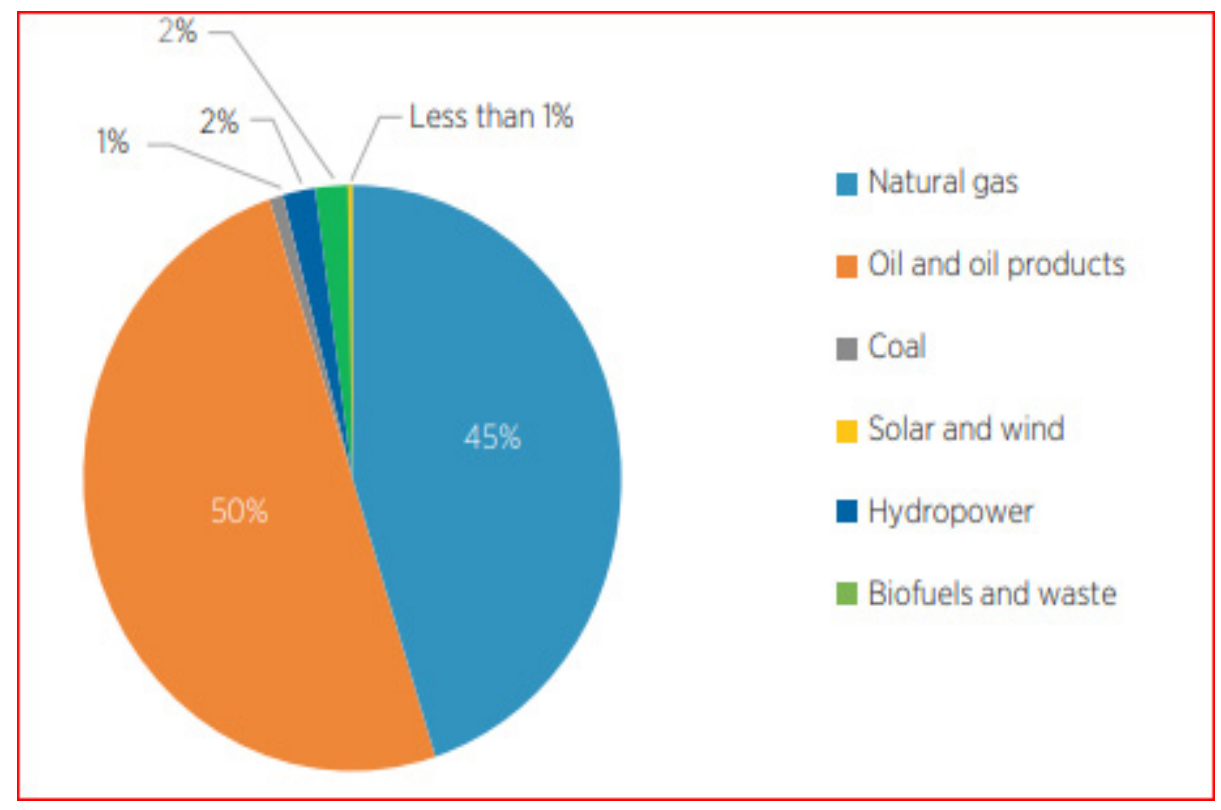

Fig. (1): Total primary energy supply in 2014/15 (IEA .,2017) 
4(c): Geothermal energy: The most common of the geothermal resources of Egypt are chiefly present along the Gulf of Suez and Red Sea with a surface temperature range of 40 $-76^{\circ} \mathrm{C}$. Some other areas are found in the Western Desert of Egypt, near to the Oasis (Baharia and Dakhla).

Hammam Faraun geothermal spring is the best place for such an investment. Away from the Gulf of Suez, some other thermal springs (up to $35^{\circ} \mathrm{C}$ ) rich in sulphur are located $25 \mathrm{~km}$ south of Cairo close to Helwan city. In the Western Desert of Egypt, hot water is produced from some deep artesian wells. The temperature is in the range from 35 $450 \mathrm{C}$. These places can be used for low and direct geothermal applications (district heating "especially in winter", swimming pools, medical therapy, green houses, etc.) ( Lashin ,2015)

4- Environmental impacts of different renewable energy technology:

All sources of energy have significant negative impact on the environment that varies according to the specific technology used. Researches demonstrated that fossil fuels, natural gas and oil have the most deleterious effect on the environment including air and water pollution, damage to public health, wildlife, and global warming. This drives the governments for shifting from fossil fuels to renewable energy for electricity generation. Developing renewable energy technologies that / the sun, the wind, and geothermal energy is critical to addressing concerns about climate change and some environmental issues (Sung and Park, 2018).

It is crucial to understand potential environmental issues associated with each renewable energy source to address proper mitigation procedures (Sørensen et al., 2009).

\section{5(a) - Solar energy}

Environmental impact of solar energy generation might include land use and habitat loss, water use, however manufacturing process might use of hazardous materials that vary greatly depending on the technology used either it is photovoltaic (PV) solar cells (single crystalline, multicrystalline, amorphous silicon, copper-indium-galliumdiselenide [CIGS] and Cadmium Telluride (CdTe) or concentrating solar thermal plants (CSP). Solar power is reshaping energy markets around the world. In the decade from 2007 and 2017 the world's total installed energy capacity from photovoltaic panels (PV) increased an enormous 4,300 percent. 
Solar photovoltaics module (PV) is the technology of transforming solar energy directly to electricity, using semiconductor devices (solar cells) and it has experienced the most rapid cost declines more than $90 \%$ since 2010 . It is stated that cost reductions in renewable and advances in digital technologies are initiating many opportunities for energy transitions (IEA, 2019).

The PV cell manufacturing process includes a number of unsafe materials, most of which are used to clean and sanitize the semiconductor surface. These chemicals, similar to those used in the common semiconductor industry, include hydrochloric acid, hydrogen fluoride, acetone, sulfuric acid, 1,1,1-trichloroethane, and nitric acid. The amount and type of chemicals used depends on the kind of cell, the amount of cleaning that is needed, and the size of silicon wafer. Workers also face hazards associated with inhaling silicon dust (National Renewable Energy Laboratory (NREL) (2012).

Another technology is the use of solar panels called, concentrating solar power (CSP), converts the sun's light to electricity, by using mirrors to concentrate the sun's heat, deriving thermal energy instead. Egypt receives over 4,000 hours of sunshine per year, which is among the highest quantities registered in the world. Egypt installs one of the largest scale solar power project in the world, Benban Solar Park generating $1.8 \mathrm{GW}$. (https://www. nationalgeographic.com/environment/ energy/reference/renewable-energy/).

Concentrating solar thermal plants (CSP), like all thermal electric plants, need water for cooling. Water use depends on the plant design, plant site, and the kind of cooling system.

CSP plants that use wet-recirculating technology with cooling towers withdraw between 600 and 650 gallons of water per megawatt-hour of electricity produced. Dry-cooling technology can reduce water use at CSP plants by approximately 90 percent .However, the tradeoffs to these water reserves are higher costs and lower efficiencies. In addition, dry-cooling technology is significantly less efficient at temperatures above 100 degrees Fahrenheit $\left(37.7^{\circ} \mathrm{C}\right)$ (National Renewable Energy Laboratory (NREL) (2012).

Land impacts from utility-scale solar systems can be minimized by putting them at lower-quality places such as brown fields, discarded mining land, or existing transportation and transmis- 
sion corridors. Smaller scale solar PV arrays, which can be built on homes or commercial buildings, also have minimal land use impact.

However, the investment cost of solar power plants is currently very high in comparison with fossil hydrocarbon based power plants (Lashin , 2015).

\section{5(b) -Wind energy}

Egypt has a high potential for wind energy, especially in the Red Sea coast area. Wind produces no air or water pollution, involves no toxic or hazardous substances and poses no threat to public safety, so it is considered the cleanest and most sustainable mean for generating electricity. Wind is also profuse, inexhaustible, and affordable, which makes it a possible and largescale alternative to fossil fuels ( https://www.ucsusa.org/resources/ environmental-impacts-renewableenergy-technologies)

It might have challenges to wildlife and habitat and also contribute to aerodynamic noise from commercial wind turbines moving parts, especially the gearbox. Technological advances, such as decrease blade surface imperfections and using sound-absorbent materials can diminish wind turbine noise
(Bastasch et al., 2006)

Wind turbines may also scatter electromagnetic signals causing interference to communication systems ( $\mathrm{Pa}$ tel \& Shrivastava., 2009). Most wind power comes from onshore turbines, but offshore projects are appearing too (Crnković et al., 2010). Offshore wind facilities require large space because the turbines and blades are bigger than their land-based counterparts. Depending on their site, such offshore installations may compete with different types of other sea activities, such as fishing, oil and gas extraction, navigation, recreational activities and aquaculture (https://www.ucsusa.org/resources/ environmental-impacts-wind-power)

\section{5(c) - Hydroelectric power}

Hydroelectric power includes large scale hydroelectric dams that continue to be built in many parts of the world or small run-of-the-river plants and both are associated with environmental impacts.Hydroelectric facilities can have a chief effect on aquatic ecosystems( for example, fish and other organisms can be injured and killed by turbine blades). Also it can decrease biological diversity or change water quality (Patel and Shrivastava, 2009). 
Flooding land for a hydroelectric reservoir has an great environmental impact: it destroys agricultural land, wildlife habitat and scenic lands. In many instances, such as the High Dam in Aswan, entire communities had also to be relocated to make way for reservoirs. This occurred when Lake Nasser was produced as a result of the Nile River being blocked. As a result, more than 120,000 people in Egypt (lower Nubia) and Sudan had to be resettled. Some were moved to a newly formed buildings along the shore of the lake, while others were moved more than 45 kilometers away to lands that were completely foreign to them ( https://visionlaunch.com/aswan-damenvironmental-impact/) .Also when the Aswan high dam was built, the entire Temple of Abu Simbel was moved, so it wouldn't be flooded and damaged when Lake Nasser filled up as well as also shifted Philae, Kalabsha and Amada temples to different places to maintain the treasures of the Ancient Egyptians safe (https://www.mbarron.net/Nile/ envir_nf.html).

Apart from direct contact, there can also be wildlife impacts both within the dammed reservoirs and downstream. Reservoir water is usually more stagnant than normal river water. As a result, the reservoir will have elevated than normal amounts of sediments and nutrients, which can cultivate an excess of algae and other aquatic weeds. These weeds can crowd out other river animal and plantlife, and they must be prohibited through manual harvesting or by introducing fish that eat these plants. In addition, water is lost through evaporation in dammed reservoirs at a much advanced rate than in flowing rivers ( $\mathrm{https}: / /$ en.wikipedia. org/wiki/Aswan_Dam\#Environmental_ and_cultural_issues)

Reservoir water is low in dissolved oxygen and colder than normal river water. When this water is released, it could have negative impacts on downstream plants and animals. To reduce these impacts, aerating turbines can be placed to increase dissolved oxygen and multi-level water intakes can help to ensure that water released from the reservoir comes from all levels of the reservoir, rather than just the bottom (which is the coldest and has the lowest dissolved oxygen) (Biswas and Tortajada, 2012)

\section{5 (d) - Biomass}

Biomass - plant material and animal waste - can be used to create transportation fuels and generate electricity. 
Sources of biomass resources for producing electricity are various, ranging from energy crops (like switch grass), corn stover (i.s. stalks and leaves), to agricultural waste left behind after harvest, manure, wheat and rice straw, household garbage, vegetative and urban waste. Both the type of feedstock and the way in which it is developed and harvested significantly affect land use and the power produced from biomass (https://www.ucsusa.org/resources/biomass-resources-united-states\#. VurSfuIrIdU)

Biomass power plants have some similarities with fossil fuel power plants: both involve the combustion of a feedstock to generate electricity. Thus, biomass plants were like, but not identical, concerns about air emissions and water use as fossil fuel plants (https://www.ucsusa.org/resources/ environmental-impacts-renewableenergy-technologies). The main outcome of aching is bonding of oxygen in the ash mainly as oxides, silicate, phosphates, hydroxides, and carbonate residual minerals. Carbon is partially retained as carbonates and graphite (charcoal). Nitrogen is dominantly released to the flue gas, while sulfur is mostly retained in the ash sulfates. The majority of the alkali metals ( $\mathrm{Li}, \mathrm{K}, \mathrm{Na}$ and RB) will substantially modify soil if applies as fertilizer ( Peter et al , 2013).

\section{6-Life Cycle Uses for}

\section{Environmental Impact Assessment of} different Energy Sources:

Life Cycle Assessment (LCA) is used by the national or regional scale for environmental impact assessment that attempt to capture impacts from every phase of the project, for comparison between different energy sources (Gagnon et al.,2002). It is a method to characterize the average impact of a typical facility for comparisons and planning and is commonly reported with a Net Energy Ratio (NER). NER is defined as the ratio of useful energy output to the network to the fossil or nuclear energy consumed during the lifetime of the project starting from the extraction of raw materials to the decommissioning of a facility and the disposal of equipment. Life-cycle emissions from renewable energy use are small compared with those from fossil fuel plants. (https://books. google.de/books?id=FZ2VUOX1gb AC\&pg $=$ PA 119\&dq $=$ Life + Cycle $+U$ ses + of + Energy $\& h l=$ en $\&$ sa $=X \& v e d=$ 0ahUKEwjlgNqe3ODnAhXoQhUIH dylAOgQ6AEIbDAI\#v=onepage \&q 
$=\mathrm{Life} \% 20 \mathrm{Cycle} \% 20 \mathrm{Uses} \% 20 \mathrm{of} \% 20 \quad$ lar energy, the strength of the resource Energy\&f=false).

For renewable energy sources, NERs are expected to be greater than one, indicating a positive return of energy investment. For fossil-fuel and nuclear technologies, NERs are smaller than one, with average estimates of $0.3,0.4$, and 0.3 for coal, natural gas, and nuclear power, respectively. Renewable energy sources NERs are strongly influenced by a number of underlying assumptions, such as plant capacity and life expectancy. For electricity generation from wind and so-

(which will affect the capacity factor of the installed technology) is also a critical assumption. For silicon PV specifically, the NER is highly dependent upon the thickness of the wafer and the efficiency of the cell/module produced. The highest estimated NERs are generally for wind, followed by biopower and then solar PV (Fig.2). Hydropower is also expected to have high NERs, although the results shown in the graph, from a single study, are not as high as anticipated (Gagnon et al., 2002).

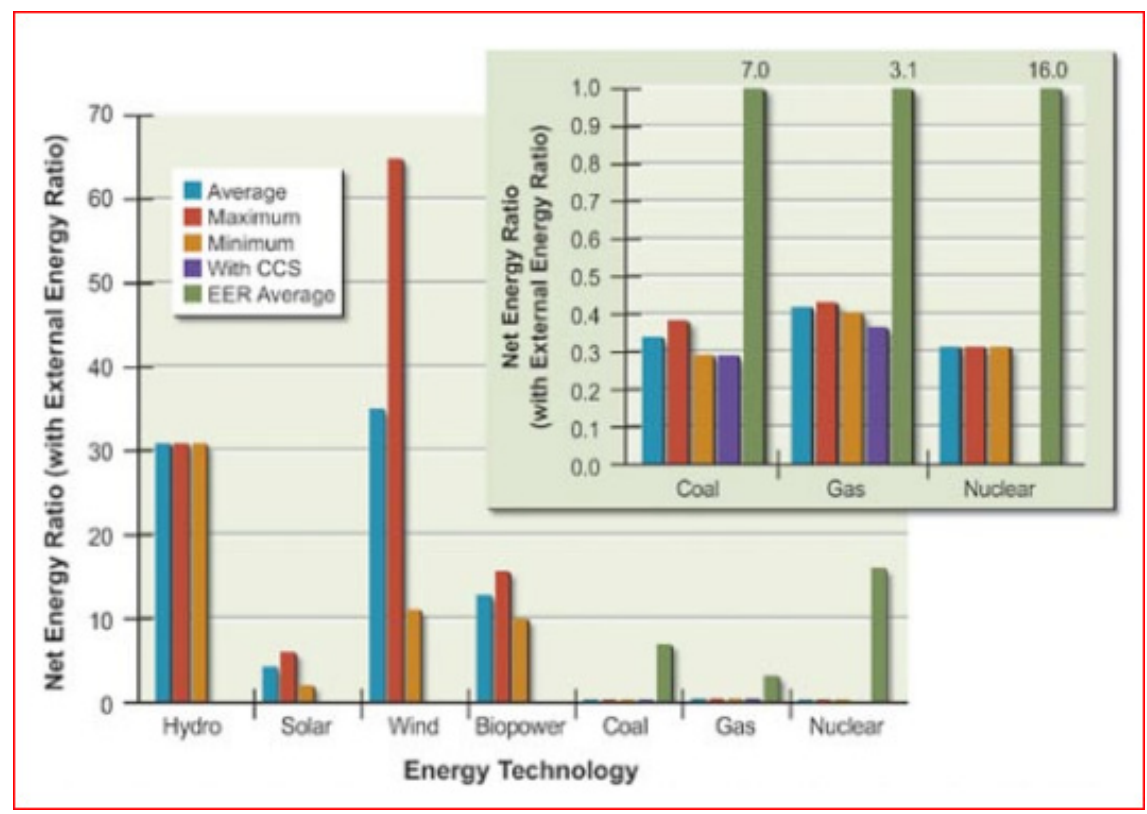

Figure (2): Net energy ratios for various renewable and non-renewable energy sources. Source: NAS/NAE/NRC, 2010a. (https://www.nap.edu/ $\mathrm{read} / 12619 /$ chapter/7\#198) 


\section{7-Conclusion}

The type of renewable sources of energy and its intensity of environmental impacts varies depending on the geographic location, the specific technology used, and a number of other factors. By understanding the current and possible environmental issues related with each renewable energy source, we can act to effectively avoid or reduce these impacts as they become a greater part of our electric supply.

\section{8-Recommendations:}

To meet the ambitions of renewable energy targets set by the government, studying the adverse environmental impacts of various sources is mandatory. Awareness by EIA is needed for planning, based on preventive approach before installing any renewable energy system and ensures proper selection of project site. Efforts should be directed towards increasing role of different renewable energy sources in the mix of fuels.

\section{References}

1. Bahgat G (2013): Egypt's Energy Outlook: Opportunities and Challenges. Mediterranean Quarterly; 24(1):13.

2. Bastasch M, van Dam J, Søndergaard B and Rogers A (2006): Wind Turbine Noise - An Overview. Can Acoust; (34:2): 7-15.

3. Biswas A and Tortajada C (2012) : Impacts of
Large Dams: A Global Assessment, 379

Water Resources Development and Management, DOI 10.1007/978-3-642-23571-9_17.

Available at: https://www.researchgate.net/ publication/234129914_Impacts_of_the_High_ Aswan_Dam

4. Crnković D, Šljivac D and Stojkov M (2010): Influence of Wind Power Plants on Power System Operation - Part One: Wind Power Plant Operation and Network Connection Criteria. Tehnički vjesnik; 17(1): 101-8.

5. Edenhofer O, Pichs C, Madruga R, Sokona Y, Seyboth K, et al., (2011): Renewable Energy Sources and Climate Change Mitigation. Cambridge: Cambridge University Press. 10.1017/CBO9781139151153

6. EIA (Energy Information Administration) (2018): Country Analysis Brief: Egypt. Retrieved from: https://www.eia.gov/beta/ international/analysis_includes/countries_long/ Egypt/egypt.pdf. and https://energypedia.info/ wiki/Egypt_Energy_Situation\#Hydro.

7. Gagnon L, Belanger C and Uchiyama Y (2002): Life-cycle assessment of electricity generation options: The status of research in year 2001. Energy Policy; 30(14):1267-8. DOI: 10.1016/ S0301-4215(02)00088-5.

8. IEA (International Energy Agency) (2017): IEA Energy Balances for 2015, Egypt, OECD/IEA, Paris. Available at: www.iea.org/ Sankey/\#? $\mathrm{c}=$ Egypt\&s$=$ Balance.

9. IEA (International Energy Agency) (2019): World Energy Outlook 2019. Available at https://www.iea.org/reports/world-energyoutlook-2019/renewables\#abstract [Accessed 29 $9^{\text {th }}$ Feb. 2020].

10. Jacobson MZ, Delucchi MA, Bazouin G , Bauer ZA, Heavey CC et al. (2015) : $100 \%$ clean and renewable wind, water, and sunlight (WWS) all-sector energy roadmaps for the 50 United States". Energy Environ Sci ; 8 (7): 2093-2117. doi:10.1039/ C5EE01283J. Available at : https://pubs. 
rsc.org/en/content/articlelanding/2015/ee/ c5ee01283j\#!divAbstract

11. Kumar M (2020): Social, Economic, and Environmental Impacts of Renewable Energy Resources.DOI:10.5772/intechopen.89494. Available at https://www.intechopen. com/online-first/social-economic-andenvironmental-impacts-of-renewable-energyresources

12. Lashin A (2015): Geothermal resources of Egypt: Country Update. Proceedings World Geothermal Congress; Melbourne, Australia, 19-25 April 2015. Available at https:// pangea.stanford.edu/ERE/db/WGC/papers/ WGC/2015/01073.pdf

13. National Renewable Energy Laboratory (NREL) (2012): Renewable Electricity Futures Study. Hand MM, Baldwin S, DeMeo E, Reilly JM, Mai T, et al. eds. 4 vols. NREL/TP6A20-52409. Golden, CO: National Renewable Energy Laboratory. Available at (https://www. ucsusa.org/resources/environmental-impactssolar-power)

14. Pablo-Romero M, Román R, Sánchez-Braza A and Yñiguez R ( 2016): Renewable Energy, Emissions, and Health. DOI: 10.5772/61717. Available at https://www.intechopen.com/ books/renewable-energy-utilisation-andsystem-integration/renewable-energyemissions-and-health

15. Park S (2015): American Security Project (ASP)'s Report on Energy in Egypt: Background and Issues. Retrieved From: https://www. americansecurityproject.org/wp-content/ uploads/2015/03/Ref-0190-Energy-in-EgyptBackground-and-Issues.pdf.

16. Patel S and Shrivastava S (2009): Environmental Impacts of Renewable Energy Technologies. National Conference on Emerging Trends in Mechanical Engineering, 20 - 21 March, 2009. MED, GH Patel College of Engineering and Technology, Vallabh Vidyanagar - 388120 .

17. Peter T, Chaowei Y, Bryan MJ and Charles EL (2013): Inorganic Composition and
Environmental Impact of Biomass Feedstock. Energy Fuels; 27(7): 3969-87.

18. Shahzad U (2015): The need for renewable energy sources. International Journal of Information Technology and Electrical Engineering; 16-18. ISSN: $\square$ 2306 $\square 708 X$.

19. Sørensen B, Breeze P, Storvickt, Yang S, et al. (2009): Renewable Energy Focus Handbook. Academic Press.

20. Sung B and Park S (2018): Who Drives the Transition to a Renewable-Energy Economy? Multi-Actor Perspective on Social Innovation. Sustainability; 10(2): 448. Available at https:// doi.org/10.3390/su10020448

21. http://www.conserve-energy-future.com/ disadvantages_fossilfuels.php, "Fossil Fuels" [Accessed 20 ${ }^{\text {th }}$ Feb. 2020]

22. https://www.nationalgeographic.com/ environment/energy/reference/renewableenergy/ [Accessed $18^{\text {th }}$ Feb. 2020]

23. https://books.google.de/books?id=FZ2VUOX $1 \mathrm{gbAC} \& \mathrm{pg}=\mathrm{PA} 119 \& \mathrm{dq}=\mathrm{Life}+\mathrm{Cycle}+$ Uses + of + Energy\&hl $=$ en\&sa $=X \& v e d=0 a h U K E w j l g N q$ e3ODnAhXoQhUIHdylAOgQ6AEIbDAI $\# \mathrm{v}=\mathrm{o}$ nepage $\&$ q $=$ Life $\% 20$ Cycle $\% 20$ Uses $\% 20$ of $\% 20$ Energy\&f=false [Accessed $21^{\text {st }}$ Feb. 2020]

24. https://spectrum.ieee.org/energywise/energy/ renewables/egypts-massive-18gw-benbansolar-park-nears-completion [Accessed $26^{\text {th }}$ Feb. 2020]

25. https://www.oecd.org/greengrowth/greeningenergy/49157219.pdf [Accessed $26^{\text {th }}$ Feb. 2020]

26. https://www.nap.edu/read/12619/chapter/7\#198 [Accessed 28 ${ }^{\text {th }}$ Feb. 2020]

27. h t t p s : // w w w e g y p t oday.com/ Article/2/62730/2018-The-year-of-newrenewable-energy [Accessed $29^{\text {th }}$ Feb. 2020]

$28 . \quad$ https://wwww.dailynewssegypt. com/2020/01/15/a-positive-outlook-forrenewable-energy-investments-in-egypt/ [Accessed $8^{\text {th }}$ March 2020]

29. https://www.energycharter.org/fileadmin/ DocumentsMedia/Occasional/Egypt_and_the Charter.pdf [Accessed $8^{\text {th }}$ March 2020] 
30. cigionline.org/articles/ipcc-report-will-haveprofound-effects-climate-governance?gclid $=\mathrm{E}$ AIaIQobChMIluzV1OiK6AIVWofVCh2PTgY 0EAAYASAAEgKVhfD_BwE [Accessed 21 Feb. 2020]

31. https://www.ucsusa.org/resources/ environmental-impacts-solar-power (REPORTS \& MULTIMEDIA / EXPLAINER, Environmental Impacts of Solar Power, Published Mar 5, 2013)

32. https://www.ucsusa.org/resources/ environmental-impacts-renewable-energytechnologies

33. https://www.ucsusa.org/resources/biomass-resources-united-states\#.VurSfuIrIdU

34. https://en.wikipedia.org/wiki/Renewable_energy.

35. https://www.ucsusa.org/resources/environmental-impacts-wind-power

36. https://en.wikipedia.org/wiki/Aswan Dam\#Environmental_and_cultural_issues

37. https://www.mbarron.net/Nile/envir_nf.html 
